\title{
Interrelationship of Corruption and Ecological Disaster
}

\author{
Muhammad Rustamaji ; Bambang Santoso ${ }^{\star \star}$ \\ Universitas Sebelas Maret (UNS) Solo- Indonesia \\ ^hatchi_ajie@yahoo.com

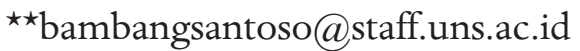

\begin{abstract}
Human being and living quality of their global community very depends on environmental condition. Then, various policies, regulation managements, law enforcement and technical supervision are conducted in attempts of biological environment conservation. However, corruption has always been primary enemy for all aspects of the environmental conservation. Apart from all efforts that had been conducted, natural resource sector is, in fact, a fertile land for corruption. Unguaranteed property right aspect, unbalanced discretion, complexity management of natural resource product, and weakness of control are factors leading to ecological environment become vulnerable area of corruption. Ultimately, bad impacts of the environmental damage return to human being as ecological disaster on individuals as well as global people. Therefore, efforts of prevention such as to involve people in recognizing forms of corruption contributing to ecological disaster is important. Grand corruption (state capture $\&$ elite capture), middle class corruption and petty corruption are forms of corruptions of ecological environment that should be understood deeply by people.
\end{abstract}

Keywords: Ecological Disaster; Corruption; Involving Society

\section{A. Background}

Corruption as the root of national whole problem apparently con- 
tributes greatly to the ecological disaster. Destructive force of corruption behavior also applies to natural resources sector, living environment, and ecology. As a result, man as an individual or a group of global society must bear environmental damage in form of ecological disaster. Losses due to ecological disaster is not limited to financial losses suffered by state, but also value of biodiversity loss, climate change, global warming, abnormal functional of hydrology as well as social value resulting from the disaster and, loss of life resource as excess of ecosystems destruction. If the ecological disaster has occurred, it is not only impacting policy makers, but in fact the whole community shared the excesses directly. Therefore, community participation, particularly in prevention of ecological disaster due to the exploitative corrupt behavior plays an important role.

Corruption is a trigger factor affecting conditions of environment and natural resources. World Economic Forum (WEF) noted that the higher level of corruption in a country, the greater environmental damage occurred, and the lower level of environmental sustainability ${ }^{1}$. The Center for People Empowerment in Governance (CenPEG) stated that many developing countries rely heavily on extractive industries such as mining, deforestation, natural resource exports, and industries that are familiar with cases of corruption ${ }^{2}$.

Although both organizations did not specifically mention the name of the state, but as a developing country such a thesis should be a serious warning for Indonesia. Cadara noted that corruption of the natural resources sector can occur for at least three reasons. The reasons of weak regulation of property right, imbalanced supply and demand of natural resources, presence of discretion and low integrity of the state apparatus ${ }^{3}$, open a rampant behavior of corruption in environmental sector. The Cadara's portray can be parsed further, namely, the first, it is on the part of developing countries including

1 Global Risks 2014, Ninth Edition, Geneva: World Economic Forum, 2014, p.46

2 Wilfredo B. Carada, Korupsi, Sumber Daya Alam, dan Isu Lingkungan (Corruption, Natural Resources, and Natural Issues), in Korupsi Mengkorupsi Indonesia, Jakarta: Gramedia Pustaka Utama, 2009, p. 243-244

3 Ibid, p. 246-247 
Indonesia in which the setting of property rights is relatively weak, so that careless exploitation of the environment is not controlled. The fact showing that natural resources generally located in remote areas is increasingly confirming indication that there has been massively no effective control. Moreover, state's revenue leakage cannot be avoided. Second, the imbalance between very high demand for natural resources and the limited supply. Consequently, access to natural resources become commodities vulnerable to corruption. Business's high interests with access to natural resources led to no longer healthy competition, because there is greater possibility of bribe and gratification incident among low-integrity government officials. The fact that natural resource management needs long and complicated processes of exploration, extraction, production, and trading, put only big players who can access the authorized officials. The complexity of natural resource management is opening the potential for corruption. Third, vulnerability of corruption can also be present as a result of enactment of too broad or too weak discretion. Countries with broad discretion in certain bureaucrats and politicians will cause great opportunity for discretion holders to misuse their discretionary powers. On the contrary, too weak discretion will debilitate the state, so that private sectors will easily take over the authority of the state (state capture). The private sector can easily buy decision makers to perform legal instrumentation. Legal umbrella is used as a tool to smooth policies and regulations benefiting a particular party as well as opening opportunities for corruption at the lower level.

Observing carefully the vulnerability of corruption occurrences in each levels of natural resource management, community involvement becomes important to prevent them. Massive corruption should be seen as a social problem ${ }^{4}$, no longer as a legal issue merely. The shift of perspectives on legal issues toward social issues is what encourages community involvement to understand various forms of corruption in order to prevent ecological disaster.

4 Achmad Gunaryo, Dari Rule of Law Menuju Rule of Social Justice (From the Rule of Law Towards the Rule of Social Justice), in Menggagas Hukum Progresif Indonesia, Yogyakarta: Pustaka Pelajar,2012, p.33 


\section{B. Method of Study}

Adji Samekto argued that the science of law can be explained in two different categories. First, it is as a normative study with its object is law as a concept of system of positive norms set of people life. Such studies provide direction for legal research to determine what legal principles that should be applied and not. Second, the legal science can be seen as a scientific study intending to explain (explanation), criticize, and then, construct a new provision, or build a theory (theory building) $)^{5}$. This study belongs to the second category, namely the analysis is directed to examine the science of law as a scientific study ${ }^{6}$. Such scholarly study is obtained from reading of results of researches and literatures on various forms of corruption and varied causes of environmental destruction in Indonesia. This secondary data is, then, analyzed qualitatively in order to explain about corruption and its interrelationships with environmental damage and ecological disaster. The study is directed toward a critical point regarding to involvement of community in recognizing various forms of corruption that are very destructing ecological and environmental conservation order.

\section{Review of Related Literature}

Studying a human existence and urgency of environmental sustainability supporting it presumably cannot negate various forms of corruption at all levels of environmental management sector. Instrumentation of laws in attempts of committing corruptions very damaging to environment would compel effort of finding the basic theorization of law, namely 'law and human relations '. Such portray of law and human relevance can be projected as follow: as a theory is based on regulatory factors, then, its movement increasingly regards the law as a formal-legalistic closed unit. Consequently, the law is

5 FX. Adji Samekto, Ilmu Hukum dalam Perkembangan Pemikiran Menuju PostModernisme (Legal Studies towards the Paradigm of Postmodernism), Bandar Lampung: Indepth Publishing, 2012, p.v

6 FX. Adji Samekto, Studi Hukum Kritis: Kritik Terhadap Hukum Modern (Critical Legal Studies: Critics towards Modern Law), Semarang: Badan Penerbit UNDIP, 2003, p. i 
only used as a tool to legalize acts of environmental destruction. But on the contrary, when it uses human aspects as it foundations, the theory will be more open and touch pieces of humanistic social mosaic, not least environment supporting existence of human life.

Movement of the theory toward two poles, both sides of the legal rules and the human side, according to Bernard L. Tanya, is classified into two types as 'human order'. The first type produces legalism, Ideenjurisprudenz, Begriffsjurisprudenz, Analytical Jurisprudence, Reine Rechtslehre, or Rechtdogmatiek. While, the second type produces, among the other, theories of nomos and justice, Frei Rechtslehre, Historism, Interessenjurisprudenz, Sociological Jurisprudence, Realistic Jurisprudence, Critical Legal Theories and Responsive Law and Progressive Law?.

Based on the picture about an array of legal theories above, the paper bases itself on concept of deep ecology of Progressive Law's principles. This means that the discussion is not conducted in areas of legalistic formal study paying attention only to the rules/positive law $^{8}$ regarding to interrelationships of corruption and ecology. The study is more directed to human side as an agent who is reacted based on action, not only on text of the law. Homes formulated it with the words 'the life of the law has not been logic; it has been experience's.

7 Bernard L. Tanya et. al, Teori Hukum, Strategi Tertib Manusia Lintas Ruang dan Generasi (Legal Theory, the Strategy of Human Order, Across Time and Generation), Yogyakarta: Genta Publishing, 2013, $4^{\text {th }}$ ed., p. vii

8 Kelsen argued, that the pure legal theory is a theory of positive law. As a theory, it is mainly intended to identify and explain its purpose. The theory seeks to answer the question of what the law is and how it is there, not how it should be there. Hans Kelsen, Pure Theory of Law, Fundamentals of Normative Legal Studies, London: Nusamedia, 2013.10 ${ }^{\text {th }}$ ed., p. 1

9 Satjipto Rahardjo, Hukum Progresif: Aksi, Bukan Teks (Progressif Law, an Action instead of Text), in Memahami Hukum 'dari Konstruksi sampai Implementasi’, Jakarta: Rajagrafindo Persada, 2011, p. 4 


\section{Discussion}

\section{Forms of Corruption in The Field of Natural Resources}

Rahardjo once suggested that the study of law is a very broad discussion and arguably, it may be called barely unlimited ${ }^{10}$. Therefore, the discussion about corruption of environmental sector in this paper is not limited on merely written and textual rules. According to ideas of progressive law, the law is for man, not vice versa. Therefore, although a man started to practice law by text, but next the work is taken over by the man himself/herself. This means that the man will find deeper meaning of texts of the law, so that he or she should be involved in carrying out the law ${ }^{11}$.

Focus the discussion to ecological management of each stage, undeniably anymore that it is a fertile ground for corruption. Start from development of policies and regulations, level of regulation enforcement, permit and license issues, compliance testing and inspection. Such picture of corruption is at least providing mapping of interactions between political and economic actors about potentials for corruption ${ }^{12}$. The potential of corruption is, then, introduced to the public, so that everyone plays an active role to prevent it.

As in other sectors, other forms of corruption occurring in the environmental sector can be categorized as follow: grand corruption (state capture and elite capture), middle class corruption and petty corruption $^{13}$.

10 According to Rahardjo, legal study is exploring up to territories of culture, economics, history, politics, philosophy, management and sociology. Satjipto Rahardjo, op.cit, p. 1

11 Bernard Arief Sidharta, Ilmu Hukum Indonesia, Upaya Pengembangan Ilmu Hukum Sistematik yang Responsif Terhadap Perubahan Masyarakat (Indonesian Legal Science, An Effort of Developing a Sistematic Legal Science for Social Change), Yogyakarta: Genta Publishing, 2013, p. 60

12 Arvin K Jain, "Corruption: A Review ", Journal of Economic Survei, Vol.15, No.1, Concordia University, p.74

13 Wilfredo B. Carada, op.cit. Compare with opinion of Wijayanto who groups thousands of corruption behaviors in two major categories, namely grand corruption and petty corruption by referring to the amount of funds, operational mode, and level of public officials involved in it. Wijayanto, Mema- 
1. The Grand Corruption

The grand corruption is closely related to the abuse of power by public officials involving large illegal transaction. The low-integrity high officials were willing to sacrifice forest, biodiversity, clean air and water, and ecological wealth in order to achieve their political agenda and greed. The grand corruption is also referred to Kleptocracy ${ }^{14}$. Type of the corruption is classified as a form of taking-over state's authority (state capture).

Major corruption was originated from lack of transparency and accountability decision-making process including creation of regulations and laws in environmental sector. Owners of great capital with their financial strength participated to influence policy makers to favor the investors' interests. The resulting law was ultimately unable to open the mustbe -exist transparency and accountability. The law was only an instrument ${ }^{15}$ to perpetuate grand corruption disguised behind power. Concentration of power in a particular official is also a major cause of big corruption destructing ecology. The officials can loosely issue discretion and commit nepotism to

hami Korupsi, Kumpulan Tulisan Korupsi Mengkorupsi Indonesia, Sebab, Akibat, dan Prospek Pemberantasan (Understanding Corruption), Jakarta: Gramedia Pustaka, 2009, p. 17

14 Cleptocracy is a term applied to indicate the most serious level of corruption in a country. Green (2004) which refers to the formulation of Weber's kleptocracy, namely, to make a profit through corruption as the organization's goals, boundaries of interests of state and the ruler become blurred, which is a door for corruption. Kleptocracy is also called high-level corruption (heavy corruption). Muhammad Mustofa, "Kleptokrasi: Permufakatan Korupsi Birokrasi dan Korporasi, Suara Pembaharuan daily, Wednesday, June 4, 2008, p. 10 col. 4.

15 Legal instrumentation in the time of the Old Order were the law was a tool of power, so that the establishment or enforcement is always intervened as the releases of various decrees of President and enablement for the President in intervening judicial process; whereas in the New Order era, the same thing happened but it was provided with a package (shaping) of official rules enforced. Moh. Mahfud MD, Membangun Politik Hukum, Menegakkan Konstitusi (Establishing the Politics of Law), Jakarta: Raja Grafindo Persada, 2012. $3^{\text {rd }}$ ed., p. 20 
win certain corporate's interests. Concessions as compensation from the winner of ecological managers were frequently hidden through varied ways of bribery and also ways of putting the officials in important positions of the company winning the rights of ecological exploitation. A mode of using other's name in the concession was also performed despite the fact that the ultimate beneficiaries remain on the corrupt officials.

a. State Capture

A corruption that is still categorized as grand corruption with a very serious, large scale form is state capture ${ }^{16}$. The corruption is a cunning game of big corporates who pay public officials to secure all of the rules of ecology sector in order to benefit the corporate. The World Bank defined the state capture as the non-transparent actions of individuals, groups, or public or private corporations, to influence formulation of laws, regulation, legislation, public policy, for the sake of benefit of private parties and government officials ${ }^{17}$.

One of modes developed in the state capture is bribery. The bribery strategy was committed in order to make or to interpret a product of legislation to be favorable for the bribe giver. The pattern of reduced complexity of ecological management in the narrow written rules is open interpretation as the heart of the law ${ }^{18}$. Step of deflecting interpretation of the texts favorable for the bribe giver is underlying the state capture.

Another strategy performed in the state capture is to

16 Hellman, Joel S, Geraint Jones, and Daniel Kaufman (2003), "Seize The State, Seize The Day: State Capture and Influence in Transition Economic," Journal of Comparative Economic, 31, p 751-773

17 Joel Hellman and Daniel Kaufmann, "Confronting the Challenge of State Capture In Transition Economies,” Finance \& Development (A Quarterly Magazine of The IMF), September 2001, Vol. 38, Number 3.

18 Satjipto Rahardjo, "Penafsiran Hukum yang Progresif” Introduction of Anthon Freddy Susanto’s book, Semiotika Hukum (Dari Dekonstruksi Teks Menuju Progresivitas Makna), Bandung: Refika Aditama, 2005, p. 1 
bluff the government that the investor will relocate investments to other country. The snapping is not always a tangible confrontation, but it can take a form of lobby and through financing of political party of the authorized officer. Undeniably, a leader of political party played an important role in the governmental position of the official in a democratic system. The 'bought' leader of political party was not impossible to use his or her political power to push an official who is also a member of his or her political party in order to benefit the investors who donate to the political party. Unfortunately, the study of corruption about behavior of utilizing political power in order to deflect executive power in ecological sector is still not completely done yet.

b. Elite Capture

Elite capture is a phenomenon where resource transferred for the benefit of the masses is usurped by a few, usually politically and/or economically powerful groups, at the expense of less economically and/or politically groups ${ }^{19}$. In the corruption, authorities who do not have technical competences on ecological management are making relationship with corporates who are providing benefits to them in order to perpetuate their power. The goal of accumulating personal wealth is to establish a power dynasty supported by substantial funds adequacy. Income that should be the right of the state is diverted with diverse legal instrumentation creating 'legal corruption'20.

Some modes revealed in elite capture were, among the others, determination of the understated tax. A standard selling price used to calculate royalty was at the true market value (transfer pricing). Consequently, it reduced earnings from tax and royalty. The worse bad impact is inability of the state

19 Diya Dutta, "Elite Capture and Corruption: Concepts and Definitions," National Council of Applied Economic Research-NCAER, Oktober 2009, p.3

20 Daniel Kaufman and Pedro C. Vicente, Legal Corruption (Second Draft, October 2005), (World Bank: World Bank Institute, 2005), p. 1 
to provide good public service to people. Road damage and increase of poverty in regions of mining are among extreme examples of the elite capture presence. Evenly distributed welfare has never been felt by people who live in their rich native earth, except for a handful of ruling elites.

2. Middle Class Corruption

In contrast to grand corruption, a middle class corruption ${ }^{21}$ is not conducted by high officials who hold the top power. This type of middle-level corruption is committed by middle-level public officials and local ones. Often-practiced forms of the corruption are bribery, gifts (gratification), influence selling, favoritism, nepotism and embezzlement.

Unclear provisions of ecological management are a major cause of this middle-type corruption. Gray areas in the written regulations are creating chances for different interpretations, thus it opens opportunities of corruptions. Using variety of modes that were directed toward the middle-level and local officials, investors with their own interest were exploiting the gray areas for profit. Due to many officials who occupied middle-level and local positions, then, kinds of middle corruptions will recur with a great escalation, and the accumulation will always cause great leakage of the state's income.

3. Petty Corruption

Petty corruption refers to the situation where typically lower level bureaucrats misuse their public office for private gain. The bribes involved in these illegal interactions are usually of small size and accepted on a frequent basis ${ }^{22}$. Jain describes the petty corruption as a circumstance where the public is required to bribe bureaucrats to make them do what they have to do anyway or to speed up the bureaucratic process ${ }^{23}$. In addition to these

21 Matias Warsta, Corruption in Thailand, April 22 2004 (Zurich: International Management, Asia Swiss Federal Institute of Technology, 2004), p.5

22 Behnud M. Djawadi and Rene Fahr, The Impact of Risk Perception and Risk Attitudes on Corrupt Behavior: Evidence from a Petty Corruption Experiment, (IZA: Discussion Paper N0.7383, 2013), p.2

23 Jain, A.K. (2001), Corruption: A Review... Op.Cit, p. 71-121 
definitions, activity of inspecting compliance to environmental regulations and overcoming of illegal acts, are a fertile ground for growth of the petty corruption. The petty corruption also develops when procedure of inspection is not easily understood. Low accountability also contributes occurrence of the petty corruption. Strict, complicated and complex ecological standards lead to inability of the rights holders of environmental management to fulfill them. Ultimately, transactional behaviors ${ }^{24}$ are occurred such as bribery, gratification and efforts of weakening activities of ecological inspection by offering variety of compensation.

\section{Form of Corruption Through AEC Reification, Ecological Di- saster and New Kind of Justice}

Observing more serious environmental damage as a result of unethical industrialization, Aldo Leopold very insisted that we had to abandon anthropocentric ethics. He and people with similar understanding view that all creatures - human being and the world of fauna, as well as flora - are eligible for the same dignity as fellow citizens of a biotic community. ${ }^{25}$ A similar sentiment was expressed by a Deep Ecologists who argued that human being is only an intrinsic part of the nature. They are merely a special thread in a weaving of the fabric of nature (human beings are nothing but a special stand in the fabric of nature) ${ }^{26}$

Furthermore, when the Asean Economic Community (AEC) with their design enforces the free flows of goods, people, services, and money among ASEAN countries meaning an establishment of a regional single market of the ASEAN region, what lessons can be kept in mind through this deep ecology? with this such awareness, then, the emergence of new legal subject with their inherent rights,

24 Moh. Mahfud MD, Penegakan Hukum dalam Rangka Meningkatkan Daya Saing dan Keunggulan Bangsa, speech delivereed at $37^{\text {th }}$ Anniversary of UNS, Surakarta: UPT UNS Press, 2013, p. 12

25 Aldo Leopold, A Sand County Almanac, New York: Oxford University Press, 1949.

26 Aldo Leopold, Ibid 
namely, the rights of mountain to remain protuberant vertically, the rights of sea to remain in blue and deep, the rights of trees to grow, the rights of river to keep flowing clear, the rights of roses to remain thorny, all of these are a sureness and containing a new kind of justice. Our thought say, if you want to be fair, then enable a tree to present in court. ${ }^{27}$ This means that there is now a much stronger impetus ethically to 'do not harm the environment'.

Legal right for a tree to stand before the court was put firstly by Crystoper Stone in the 1970s. He said the tree has a right to defend itself. So, a Theory of Legal Standing emerged and it is known to date. Through his writings questioning about 'should a tree have the rights?', the idea is still in effect and it gives us a background for our rights to at present to discuss about the environment. ${ }^{28}$

Considering the legal conditions experiencing a 'pull up ${ }^{29}$ by such globalization, an impartial law that is not passive in its neutral condition and impartial is required. Satjipto Rahardjo had expressed very early that law is not only the text of rules, but it can also in tangible behavior. It was stated further that behavior or human action can add and change the text. At the empirical level, it is found that role of human in the working of the law is too great to ignore. The law is not what is written and said by text. Chambliss and Seidman (1971) even say "the myth of the operation of law is given the lie daily". Therefore, in attempts of being able to see human behavior as a law, it would require a willingness to change our concept of the law,

27 Muhammad Rustamaji, "Mempertimbangkan Filsafat Kritis dan Deep Ecology dalam Pergumulan Masyarakat Ekonomi Asean(Considering the Critical Philosophy and Deep Ecology in the ASEAN Economic Community Arena" in the Proceedings of the National Seminar of Indonesia Readiness: Law Harmonization of ASEAN countries Towards ASEAN Community by 2015)," Prosiding Seminar Nasional Kesiapan Indonesia: Harmonisasi Hukum Negara-negara Asean Menuju Komunitas Asean 2015, Surakarta: Universitas Muhammadiyah Surakarta, 2015, p.103

28 Rocky Gerung, "Informant's Exposure of $2^{\text {nd }}$ Progressive Law Consortium,” UNDIP Semarang 14-15 November 2014.

29 Adi Sulistiyono \& Muhammad Rustamaji, Hukum Ekonomi Sebagai Panglima (Economic Law as a Commander), Sidoarjo: Masmedia Buana Pustaka, 2009, p.29 
which is not only a rule, but also behavior. ${ }^{30}$ Therefore, the neutral behavior showed, in fact, by the law is actually making some parties will increasingly in 'weak position' within a fierce arena of the world driven by globalization with its free competition in all lines. For that reason, the law is said to be progressive because it precisely defends the weak. At the next level, the concept of 'weak' should be defined naturally, materially, and concretely. At this position the ecology is placed in a 'weak position' of the law and, in fact, it is a legal subject that has been ignored for long period of time without any effort to care about it. Ideas that have been declaring to be pro-environment so far are actually not based on ecological reasons but economic interests.

Therefore, perception of justice is said to have been worn (obsolete) now if there is no any effort of trying to find undiscovered new sources of the justice. MEA can also be said to have no care about justice if it only puts economic interests as a spearheading to create a single market. Accordingly, in effort of avoiding the MEA from exploitative practices on ecology in free trade of ASEAN region the fair law is required to regulate it. A Fair law is one paying attention to new sources of the new law for achievement of the justice. It is important to organize a transition from the day to the next, namely justice for future generations.

A critique directed to higher education seems also necessary, when curriculum of law school has not arrived yet at a study on the rights of future generations (Intergenerational Justice). In other words, is position of the future generations as a source of future legal justice (a new source of the justice) taken into account when competition with all freedoms is held on each side of life? Or is the current law used only in utilitarian matter and deplete all available resources, yet democratically (sound of many people) it is desirable?

As an illustration, when President Jokowi explained the importance of the sea and its sea tolls and harbors of various islands in Indonesia, experts are busily analyzing development and reclamation

30 Satjipto Rahardjo, Menegakan Hukum Progresif, (Enforcing the Progressive Law), Jakarta: Kompas, 2010, p.14-15. 
technics required to implement the plan. Especially, as the plan is intended, one of many purposes, to meet deficit of beefs and they should be imported from Australia, then a massive development in East Nusa Tenggara (NTT) is planned. It is projected that NTT will be a location of raising calves provided by government and then, readyto harvest cows of the region will be distributed by using special livestock ships to transport over Indonesia. A model of cattle grazed in wide savanna of NTT and supported by livestock transporters and sea toll aiming to meet the needs of national meat. This step is projected as a solution to overcome meat deficit of the nation. However, such thinking is seemingly not to pay attention about why do people of Nusa Tenggara look as if 'anemic' to re-develop large farms as option of livelihood? In fact, empirical research showed what actually makes the farmers reluctant to pursue the very ecological friendly profession. They do afraid of livestock theft! The 'street crime' is actually a scourge for farmers of NTT since the theft has been transformed into a very massive, organized theft of livestock and involving parties with authorized power. Dahlan Iskan explained that the livestock theft occurred because the legal system was not running properly, even there was a phenomenon in which the cattle thieves demanded a ransom to the cattle owners if they want their cattle back. ${ }^{31}$ It is really not a figment. As a result, the solution by buying a special ship to transport of livestock, calves provided by the government, seashore reclamations and mangrove ecosystems supporting the establishment of sea tolls, are just as if confirming the view of Dahlan Iskan, namely it is like a physician prescribing wrongly.

The illustration depicts how the economy is still positioned as a major pendulum of prosperity achievement by ignoring the existing ecology. However, the unmatched solutions due to prioritize an unrelenting exploitation of ecology and at the same time, ignore the creative potential of the nation people is precisely what explains why forest resources as if never enough to meet nutritional needs of In-

31 Dahlan Iskan, "Soal Daging yang Ibarat Dokter Salah Resep", (About meat, It is Like a doctor writing a prescription wrongly) New Hope," Surabaya: Jawa Pos, 23 February 2015, p. 1\&11 
donesian people.

At the culmination of it, a notion of Yuswohady about five precepts to win competition in the arena of $\mathrm{MEA}^{32}$ is worthy to ponder. Creative and struggle-powered measures are more emphasized for every citizen of the nation who wants to be entrepreneur rather than solution promoting ecological exploitation for the sake of expansion of economic range. It can be seen in precept 1, the use of local advantages to kick the competitions, businessmen should use smartly local uniqueness to win the competition. A businessman with the characteristics of is called a local champion. Precept 2 , create local innovation to the make competition irrelevant, businessmen should use innovation and create a new market with minimal competition. A businessman with the characteristic is called a creative master. Precept 3 , boost excellence to beat the giant, this type of businessmen takes all-out measures to boost quality of their products or services in order to beat the competition. A businessman with such characteristic is called a quality challenger. Precept 4, build bigness mass through partnership, entrepreneur of this type is a small player who plays in a market niche, but if these small players are organized into a unity, they will have tremendous power. A businessman with the characteristics is called a longtail collaborator. Precept 5, achieve global best practices to win the foreign market, entrepreneur of this type is one focusing and concentrating highly to compete seriously in international market. A businessman with such characteristics is very special because they pursue excellences in all aspects such as capital, technology, management, human resources (HR) with world standards before entering an international market. The entrepreneur with the character is called a global chaser who has been put themselves from beginning as an entrepreneur in the best ranks of the world (global best practice).

Guided by the exposure and examples of environmental neglect above, it is time the law should be run progressively by taking creative ways to promote fighting spirit of the nation's people. Therefore, the law must arrive at the radicalness of demolishing as-

32 Yuswohady, “Panca Sila Juara MEA”, (Five Precepts as the Winner of MEA), (Jakarta: Koran Sindo, 5 April 2015,p. 3 
sumptions of the law that have been considered well established textually. In the context of MEA, the law established in the trade sector of ASEAN single market should not be indifferent to ecology and future source of justice, the nation's children, as our future generation. That is, where the law is not for itself, but for something wider and bigger. So whenever a problem is found within and with the law, then the law should be reviewed and corrected and not the human who is pushed and forced to enter schemes of the law..$^{33}$ Therefore, Satjipto Rahardjo also wrote about the necessary of putting the legal system in a large path of deep ecology. ${ }^{34}$ Thus, as the law shifts to the context of the universal life, then man is no longer the only central point. On a broader spectrum, the law is functioned not only to check the fairness, but it should produce justice, and yet a new kind of justice, namely justice for environment (ecology) and future generations (intergeneration justice). In the smaller scope, utilization of forest resources as a venue for holding of the MEA should not negate the principles of deep ecology requiring sustainability of it for future generations.

\section{E. Conclusion}

Involving community in recognizing various forms of corruption is a requisite condition when corruption is a common enemy of people. A corruption, primarily one interrelated with ecological damage, is placing community as the main actor who must fight it. Corruption can no longer only considered a legal issue, but as a social problem when corruption occurred in every level of ecological management. Grand corruption (state capture and elite capture), middle class corruption and petty corruption are forms of corruption actually found in the ecological sector and they should be thoroughly understood by every member of society.

33 Satjipto Rahardjo, Hukum Progresif: Sebuah Sintesa Hukum Indonesia (Progressive Law: A Synthesis of the Indonesian Laws), Yogyakarta: Genta Publishing, 2009, p. 32.

34 Satjipto Rahardjo, Lapisan-lapisan dalam Studi Hukum, (The Layers of Legal Studies), Malang: Bayumedia, 2009, p.11 


\section{Bibliography}

Carada, Wilfredo B., 2009, "Korupsi, Sumber Daya Alam, dan Isu Lingkungan (Corruption, Natural Resources, and Natural Issues)," Korupsi Mengkorupsi Indonesia, Jakarta: Gramedia Pustaka Utama.

Djawadi, Behnud M., and Rene Fahr, 2013, The Impact of Risk Perception and Risk Attitudes on Corrupt Behavior: Evidence from a Petty Corruption Experiment, IZA: Discussion Paper N0.7383.

Dutta, Diya,2009, "Elite Capture and Corruption: Concepts and Definitions," National Council of Applied Economic Research-NCAER, Oktober.

Gerung, Rocky, 2014, “Informant's Exposure of $2^{\text {nd }}$ Progressive Law Consortium,” Semarang: UNDIP, 14-15 November.

Global Risks 2014, Ninth Edition, Geneva: World Economic Forum. Gunaryo, Achmad, 2012, Dari Rule of Law Menuju Rule of Social Justice (From the Rule of Law Towards the Rule of Social Justice), in Menggagas Hukum Progresif Indonesia, Yogyakarta: Pustaka Pelajar.

Hellman, Joel S, Geraint Jones, and Daniel Kaufman, 2003, "Seize The State, Seize The Day: State Capture and Influence in Transition Economic," Journal of Comparative Economic.

------, and Daniel Kaufmann, 2001, "Confronting the Challenge of State Capture In Transition Economies,” Finance \& Development (A Quarterly Magazine of The IMF), September, Vol. 38, Number 3.

Iskan, Dahlan, 2015, "Soal Daging yang Ibarat Dokter Salah Resep", (About Meat, It is Like A Doctor Writing A Wrong Prescription) New Hope," Jawa Pos, Surabaya, 23 February.

Jain, Arvin K, "Corruption: A Review ", Journal of Economic Survei, Vol.15, No.1, Concordia University.

Kaufman, Daniel and Pedro C. Vicente, 2005, Legal Corruption (Second Draft, October 2005), World Bank: World Bank Institute.

Leopold, Aldo, 1949, A Sand County Almanac, New York: Oxford University Press. 
Mustofa, Muhammad, 2008, "Kleptokrasi: Permufakatan Korupsi Birokrasi dan Korporasi (Kleptokrasi: Birocracy and Cooporation Conspiracy for Corruption)," Suara Pembaharuan, Wednesday, June 4.

Mahfud MD., Moh., 2012, Membangun Politik Hukum, Menegakkan Konstitusi (Establishing the Politics of Law), Jakarta: Raja Grafindo Persada.

-, MD., Moh., 2013, Penegakan Hukum dalam Rangka Meningkatkan Daya Saing dan Keunggulan Bangsa (Law Enforcment to Enhance the Competitivenes and the Excellence of the Nation)", speech delivereed at $37^{\text {th }}$ Anniversary of UNS, Surakarta: UPT UNS Press.

Rahardjo, Satjipto, 2005, "Penafsiran Hukum yang Progresif (Progressif Legal Interpretation)," in Anthon Freddy Susanto, Semiotika Hukum (Dari Dekonstruksi Teks Menuju Progresivitas Makna), Bandung: Refika Aditama.

-, Satjipto, 2009, Hukum Progresif: Sebuah Sintesa Hukum Indonesia (Progressive Law: A Synthesis of the Indonesian Laws), Yogyakarta: Genta Publishing.

, Satjipto, 2009, Lapisan-lapisan dalam Studi Hukum, (The Layers of Legal Studies), Malang: Bayumedia.

-------, Satjipto, 2010, Menegakan Hukum Progresif, (Enforcing the Progressive Law), Jakarta: Kompas.

-------, Satjipto, 2011, "Hukum Progresif: Aksi, Bukan Teks (Progressif Law, an Action instead of Text)," Memahami Hukum 'dari Konstruksi sampai Implementasi', Jakarta: Rajagrafindo Persada.

Rustamaji, Muhammad, 2015, "Mempertimbangkan Filsafat Kritis dan Deep Ecology dalam Pergumulan Masyarakat Ekonomi Asean (Considering the Critical Philosophy and Deep Ecology in the ASEAN Economic Community Arena," Proceedings of the National Seminar of Indonesia Readiness: Law Harmonization of ASEAN countries Towards ASEAN Community by 2015), Surakarta: Universitas Muhammadiyah Surakarta.

Sulistiyono, Adi and Muhammad Rustamaji, 2009, Hukum Ekonomi Sebagai Panglima (Economic Law as a Commander), Sidoarjo: 
Masmedia Buana Pustaka.

Samekto, FX. Adji, 2012, Ilmu Hukum dalam Perkembangan Pemikiran Menuju Post-Modernisme (Legal Studies towards the Paradigm of Postmodernism), Bandar Lampung: Indepth Publishing.

--FX. Adji, 2003, Studi Hukum Kritis: Kritik Terhadap Hukum Modern (Critical Legal Studies: Critics towards Modern Law), Semarang: Badan Penerbit UNDIP.

Sidharta, Bernard Arief, 2013, Ilmu Hukum Indonesia, Upaya Pengembangan Ilmu Hukum Sistematik yang Responsif Terhadap Perubahan Masyarakat (Indonesian Legal Science, An Effort of Developing a Sistematic Legal Science for Social Change), Yogyakarta: Genta Publishing.

Tanya, Bernard L. et. Al., 2013, Teori Hukum, Strategi Tertib Manusia Lintas Ruang dan Generasi (Legal Theory, the Strategy of Human Order, Across Time and Generation), $4^{\text {th }}$ ed., Yogyakarta: Genta Publishing.

Warsta, Matias, 2004, Corruption in Thailand, April 22 ${ }^{\text {nd }}$., Zurich: International Management, Asia Swiss Federal Institute of Technology.

Wijayanto,2009, Memahami Korupsi, Kumpulan Tulisan Korupsi Mengkorupsi Indonesia, Sebab, Akibat, dan Prospek Pemberantasan (Understanding Corruption), Jakarta: Gramedia Pustaka.

Yuswohady, 2015, "Panca Sila Juara MEA", (Five Precepts as the Winner of MEA), Koran Sindo, Jakarta, 5 April. 